\title{
Analisis permintaan kredit pada Bank BPR Tanggo Rajo Kuala Tungkal
}

\author{
Rimawita*; Siti Hodijah; Candra Mustika \\ Prodi Ekonomi Pembangunan Fak. Ekonomi dan Binsis Universitas Jambi \\ *E-mail korespodensi: rimawita78@gmail.com
}

\begin{abstract}
This study aims to: 1) To analyze the development of interest rates on credit, inflation, economic growth, and demand for credit in banks at BPR Tanggo Rajo. and 2) To analyze the effect of the interest rate on credit, inflation, and economic growth on the demand for bank credit in banks at BPR Tanggo Rajo. Based on the simultaneous test results, the variables of credit interest rates, inflation, and economic growth together have a significant effect on credit demand at BPR Tanggo Rajo. Whereas in the partial only variable interest rates and economic growth have a significant and negative effect on credit demand at BPR Tanggo Rajo, while the inflation variable does not have a significant and negative effect on credit demand for BPR Tanggo Rajo.
\end{abstract}

Keywords: Credit demand, Credit interest rates, Inflation, Economic growth

\begin{abstract}
Abstrak
Penelitian ini bertujuan untuk: 1) Untuk menganalisis perkembangan tingkat Suku Bunga Kredit, Inflasi, Pertumbuhan ekonomi dan Permintaan Kredit pada perbankan di BPR Tanggo Rajo. dan 2) Untuk menganalisa pengaruh tingkat Suku Bunga Kredit, Inflasi dan Pertumbuhan ekonomi terhadap Permintaan Kredit Perbankan pada perbankan di BPR Tanggo Rajo. Berdasarkan hasil uji simultan bahwa variabel suku bunga kredit, inflasi dan pertumbuhan ekonomi secara bersama-sama berpengaruh signifikan terhadap permintaan kredit di BPR Tanggo Rajo. Sedangkan secara pasrial hanya varaibel suku bunga kredit dan pertumbuhan ekonomi yang berpengaruh signifikan dan negatif terhadap permintaan kredit di BPR Tanggo Rajo, sementara variabel inflasi tidak berpengaruh signifikan dan negatif terhadap permintaan kredit BPR Tanggo Rajo.
\end{abstract}

Kata kunci: Permintaan kredit, Suku bunga kredit, Inflasi, Pertumbuhan ekonomi

\section{PENDAHULUAN}

Bank merupakan lembaga keuangan yang kegiatannya tidak hanya menghimpun dana dan menyalurkan kembali kepada masyarakat melainkan memberikan berbagai fasilitas perbankan, selain itu juga untuk memberikan kepuasan kebutuhan kredit dalam berbagai cara.

Bank Perkreditan Rakyat didefenisikan oleh Undang-undang Nomor 10 Tahun 1998 sebagai bank yang melaksanakan kegiatan usaha secara konvensional dan/atau berdasarkan prinsip syariah yang dalam kegiatannya tidak memberikan jasa dalam lalu lintas pembayaran (Triandaru dan Totok, 2006). Dengan ketentuan ini memungkinkan BPR untuk memilih asas kegiatan usahanya apakah secara konvensional atau berdasarkan prinsip syariah Islam. BPR yang melaksanakan kegiatan usahanya secara konvensional dikenal dengan BPR dan tidak melakukan kegiatan berdasarkan prinsip syariah. Dan sebaliknya, BPR yang melaksanakan kegiatannya berdasarkan prinsip 
syariah dikenal dengan BPRS dan tidak melakukan kegiatan berdasarkan kegiatan berdasarkan prinsip konvensional (Lubis, 2010).

BPR Tanggo Rajo merupakan satu-satinya bank milik daerah dan didirikan pada Tahun 2004, hingga sampai saat ini selalu mengalami peningkatan, terakhir pada 2018 mengalami peningkatan aset hingga mencapai $7 \%$ dari tahun sebelumnya. Total peningkatan aset meliputi rasio NPL, rasio LDR, rasio CR, rasio ROA, dan rasio GOPO yang semuanya tergolong sehat.

Kegiatan BPR Tanggo Rajo pada dasarnya sama dengan kegiatan Bank Umum, hanya yang menjadi perbedaan adalah jumlah jasa bank yang dilakukan BPR Tanggo Rajo jauh lebih sempit. BPR Tanggo Rajo di batasi oleh berbagai persyaratan, sehingga tidak dapat berbuat leluasa seperti bank umum. Keterbatasan BPR Tanggo Rajo juga dikaitkan dengan misi pendirian BPR itu sendiri:

Tabel 1. Permintaan kredit pada BPR Tanggo Rajo Tahun 2017-2018 (Rupiah)

\begin{tabular}{llcccc}
\hline Tahun & Semester & $\begin{array}{c}\text { Kredit Modal } \\
\text { Kerja }\end{array}$ & $\begin{array}{c}\text { Kredit } \\
\text { Investasi }\end{array}$ & $\begin{array}{c}\text { Kredit } \\
\text { Konsumtif }\end{array}$ & $\begin{array}{c}\text { Total } \\
\text { Permintaan } \\
\text { Kredit }\end{array}$ \\
\hline 2017 & I & 1.729 .523 .550 & 985.843 .100 & 33.457 .229 .757 & 36.172 .596 .407 \\
& II & 1.145 .802 .500 & 2.838 .378 .300 & 33.669 .751 .413 & 37.653 .932 .213 \\
2018 & I & 1.555 .176 .850 & 3.342 .045 .750 & 34.857 .692 .433 & 39.754 .915 .033 \\
& II & 1.932 .171 .700 & 3.288 .104 .700 & 35.262 .961 .141 & 40.483 .237 .541 \\
\hline
\end{tabular}

Sumber : BPR Tanggo Rajo, 2020

Berdasarkan Tabel 1 dapat dilihat bahwa permintaan kredit modal kerja selama tahun 2017-2018 cenderung mengalami peningkatan, namun terjadi penurunan kredit modal kerja pada tahun 2017 semester II kredit modal kerja mengalami penurunan. Begitu juga dengan kredit investasi yang mengalami penurunan namun di tahun 2018 smester II. Sedangkan kredit konsumtif terus mengalami peningkatan setiap tahun dan persemesternya. Selanjutnya untuk total permintaan kredit setiap tahun dan persemesternya terus mengalami peningkatan.

Suku bunga kredit, inflasi dan pertumbuhan ekonomi merupakan tiga faktor utama yang mempengaruhi aktivitas permintaan kredit. Faktor ketiga tersebut, bukan saja suku bunga kredit yang mangalami perubahan dan akan berdampak terhadap terjadinya resiko suatu kredit macet dengan jumlah yang lebih besar sehingga akan menurunkan jumlah kredit akan tetapi dalam kondisi seperti yang terjadi diatas kegiatan alokasi kredit pada bank harus tetap berlansung. Selain itu kontrol dari Bank Indonesia (BI) terhadap inflasi yang terjadi sangat terbatas, karena inflasi sendiri mempunyai faktor pengaruh yang banyak. Maka sebab itu, perkiraan perkembangan perekonomian khususnya kemungkinan akan terjadinya tekanan inflasi perlu dilakukan oleh Bank Indonesia guna untuk mengurangi resiko yang terjadi (Ningsih, 2010).

Seperti yang telah diketahui bahwa dari penjelasan diatas dapat disimpulkan tingkat suku bunga kredit, inflasi serta pertumbuhan ekonomi diharapkan memberikan gambaran serta penjelasan mengenai dampak dari faktor tersebut terhadap permintaan kredit perbankan di BPR Tanggo Rajo. Berdasarkan uraian tersebut perlu dilakukan penelitian ini lebih lanjut dalam bentuk skripsi yang berjudul "Analisis Permintaan Kredit Pada BPR Tanggo Rajo Kuala Tungkal”.

\section{METODE}

Jenis data

Data yang digunakan dalam penelitian ini adalah data sekunder yaitu data yang berasal dari survei yang telah diproses dan kemudian dianalisis lebih lanjut sehingga 
dapat menghasilkan sesuatu yang berguna. Data yang digunakan berupa rentang waktu (time series) selama periode 2004-2018 yang meliputi :1).Data suku bunga kredit Kabupatan Tanjung Jabung Barat, 2).Data inflasi Kabupatan Tanjung Jabung Barat, 3).Data pertumbuhan ekonomi Kabupatan Tanjung Jabung Barat, dan 4).Data permintaan kredit Bank Tanggo Rajo Kabupatan Tanjung Jabung Barat

\section{Sumber data}

Data yang digunakan dalam penelitian ini berasal dari Kantor BPS Provinsi Jambi dan Bank Tanggo Rajo Kabupatan Tanjung Jabung Barat

\section{Metode analisis data}

Untuk menjawab masalah yang pertama yaitu menganalisis perkembangan tingkat Suku Bunga Kredit, Inflasi, Pertumbuhan ekonomi dan Permintaan Kredit pada perbankan di BPR Tanggo Rajo digunakan rumus berikut :

$$
\mathrm{GX}=\frac{X_{t}-X_{t-1}}{X_{t-1}} \times 100
$$

Dimana : $\quad$ Gx $\quad=$ Pertumbuhan rata-rata tahun 2005-2018

$\mathrm{x}_{\mathrm{t}} \quad=$ Pertumbuhan tahun pertama

$\mathrm{x}_{\mathrm{t}-1}=$ Pertumbuhan tahun sebelumnya

Untuk menjawab masalah ke dua yaitu menganalisa pengaruh tingkat Suku Bunga Kredit, Inflasi dan Pertumbuhan ekonomi terhadap Permintaan Kredit Perbankan pada perbankan di BPR Tanggo Rajo menggunakan metode analisis regresi linier berganda adapun rumus sebagai berikut (Gujarati, 2003):

Keterangan :

$$
\mathrm{PK}=\beta_{0}+\beta_{1} \mathrm{SB}+\beta_{2} \mathrm{INF}+\beta_{3} \mathrm{PE}+\varepsilon
$$

$\begin{array}{ll}\text { PK } & =\text { Permintaan kredit } \\ \text { SB } & =\text { Suku bunga kredit } \\ \text { INF } & =\text { Inflasi } \\ \text { PE } & =\text { Pertumbuhan ekonomi } \\ \beta \circ & =\text { Konstanta regresi } \\ \beta 1-\beta 3 & =\text { Koefesien regresi } \\ \varepsilon & =\text { Kesalahan pengganggu }\end{array}$

\section{Uji statistik}

Secara statistik ketepatan fungsi dalam menafsir nilai aktual dapat diukur dari nilai koefisien determinasi, nilai t statisik. Uji hipotesisi berguna untuk memeriksa dan menguji apakah koefisien regresi yang didapat signifikan atau tidak. Signifikan disini adalah suatu nilai koefisien regresi yang secara statistic tidak sama dengan nol. Jika koefisien slope sama dengan nol maka dapat diartikan bahwa tidak cukup bukti untuk menyatakan variabel tidak bebas mempunyai pengaruh terhadap variabel bebas (Gujarati, 2003)

\section{Uji simultan (Uji F)}

Menurut Gujarati (2003), uji statistik F pada dasarnya menunjukkan apakah semua variabel bebas yang dimaksudkan dalam model mempunyai pengaruh secara bersama-sama (simultan) terhadap variabel terikat secara signifikan urutan uji tersebut adalah : 
Menggunakan rumus hipotesis : $\mathrm{H}_{0}: \mathrm{b}_{\mathrm{i}}=0$

$$
\mathrm{H}_{\mathrm{a}}: \mathrm{b}_{\mathrm{i}} \neq 0
$$

Tingkat signifikan yang ditentukan adalah $\alpha=5 \%$

Dengan menggunaan $\mathrm{df}=\mathrm{n}-\mathrm{k}$, sehingga

$F=\frac{R^{2} /(K-1)}{\left(1-R^{2}\right)-(\mathrm{n}-\mathrm{k})}$

Keterangan:

$\mathrm{R}^{2} \quad=$ Koefisien determinasi

$\mathrm{K}=$ Jumlah variabel independen

$\mathrm{N} \quad$ = Banyaknya data / tahun

Kriteria pengujiannya adalah :

Jika $\mathrm{F}$ hitung $>\mathrm{F}$ tabel maka $\mathrm{H}_{0}$ ditolak

Jika $\mathrm{F}$ hitung $<\mathrm{F}$ tabel maka $\mathrm{H}_{0}$ diterima

Kesimpulannya jika $\mathrm{F}$ hitung $>\mathrm{F}$ tabel maka $\mathrm{H}_{0}$ ditolak, berarti terdapat pengaruh yang signifikan antara variabel $\mathrm{x}$ terhadap variabel $\mathrm{y}$, dan sebaliknya apabila $\mathrm{F}$ hitung $<\mathrm{F}$ tabel maka $\mathrm{H}_{0}$ diterima, artinya tidak terdapat pengaruh yang signifikan terhadap variabel y.

\section{Uji parsial (Uji t)}

Uji statistik t pada dasarnya menunjukkan seberapa jauh pengaruh satu variabel bebas secara individual (parsial) dalam menerangkan variasi variabel terikat. Urutan uji tersebut adalah:

Menggunakan rumus hipotesis : $\mathrm{H}_{0}: \mathrm{b}_{\mathrm{i}}=0\left(\mathrm{H}_{0}\right)$

$$
\mathrm{H}_{\mathrm{a}}: \mathrm{b}_{\mathrm{i}} \neq 0\left(\mathrm{H}_{\mathrm{a}}\right)
$$

Tingkat signifikan yang ditentukan adalah $\alpha=5 \%$

Kriteria pengujian:

Jika thitung $>\mathrm{t}$ tabel maka $\mathrm{H}_{0}$ ditolak

Jika t hitung $<\mathrm{t}$ tabel maka $\mathrm{H}_{0}$ diterima

Kesimpulan nya jika t hitung $>\mathrm{t}$ tabel maka $\mathrm{H}_{0}$ ditolak, berarti terdapat pengaruh yang signifikan antara variabel $\mathrm{x}$ terhadap variabel $\mathrm{y}$, dan sebaliknya apabila $\mathrm{t}$ hitung $<\mathrm{t}$ tabel maka $\mathrm{H}_{0}$ diterima, artinya tidak terdapat pengaruh yang signifikan terhadap variabel $\mathrm{x}$ dan $\mathrm{y}$.

\section{Koefisien determinasi $\left(\mathbf{R}^{2)}\right.$}

Digunakan untuk mengukur pengaruh variabel independen terhadap variabel dependen. $\mathrm{R}^{2}$ bernilai antara Nol sampai dengan satu $0 \leq \mathrm{R}^{2} \leq 1$ Dapat dihitung dengan rumus sebagai berikut :

$$
R^{2}=\frac{\sum\left(Y^{\prime}-Y\right)}{\sum(Y i-Y)}
$$

Dimana:

$\begin{array}{ll}\mathrm{R}^{2} & =\text { Koefisien determinasi } \\ \mathrm{Y}^{\prime} & =\text { Determinan }\end{array}$ 
$\mathrm{Y} \quad=$ Permintaan kredit

$\mathrm{Y}_{\mathrm{i}} \quad=$ Rata-rata permintaan kredit

\section{HASIL DAN PEMBAHASAN}

\section{Perkembangan tingkat suku bunga kredit}

Suku bunga kredit investasi merupakan suku bunga kredit yang mencerminkan sikap dari kebijakan moneter yang ditetapkan oleh bank Indonesia. Suku bunga kredit diumumkan kepada publik oleh Dewan Gebenur bank Indonesia setiap bulannya. Perubahan BI-Rate mempengaruhi suku bunga kredit perbankan, apabila perekonomian sedang mengalami kelesuan, bank Indonesia dapat menggunakan kebijakan moneter yang ekspansif melalui penurunan suku bunga kredit untuk mendorong aktifitas ekonomi. Hubungan dari suku bunga kredit dengan perbankan diambil sisi pembiyaan, penurunan suku bunga BI-Rate menurunkan suku bunga kredit sehingga permintaan akan kredit dari perusahaan dan rumah tangga akan meningkat. Dampaknya dimana saat suku bunga kredit naik maka perusahaan pembiyaan mendapatkan pinjaman dari bank suku bunga kredit yang baru. Perkembangan suku bunga kredit di Kabupaten Tanjung Jabung Barat dapat dilihat tabel dibawah ini :

Tabel 2 Data suku bunga kredit Kabupaten Tanjung Jabung Barat tahun 2004-2018

\begin{tabular}{rc}
\hline Tahun & Suku bunga kredit $(\boldsymbol{\%})$ \\
\hline 2004 & 15,68 \\
2005 & 15,66 \\
2006 & 15,10 \\
2007 & 13,01 \\
2008 & 14,40 \\
2009 & 13,65 \\
2010 & 12,63 \\
2011 & 12,12 \\
2012 & 11,27 \\
2013 & 11,82 \\
2014 & 12,36 \\
2015 & 12,12 \\
2016 & 11,21 \\
2017 & 12,38 \\
2018 & 12,42 \\
\hline Rata-rata & $\mathbf{1 3 , 0 5}$ \\
\hline
\end{tabular}

Sumber : Badan Pusat Statistik, 2020

Dari data Tabel 2, bila melihat perkembangan tahunan terlihat berfluktuasi ratarata suku bunga kredit selama periode penelitian tahun 2004-2018 adalah 13,05 persen pertahun. Suku bunga kredit tertinggi tercatat pada tahun 2004 sebesar 15,68 persen. Tingginya suku bunga kredit di Kabupaten Tanjung Jabung Barat pada tahun tersebut dikarenakan ketidakstabilan perekonomian yang terjadi di saat krisis tahun 1998 menyebabkan dampak buruk yang signifikan terhadap seluruh aspek perekonomian di Indonesia. Pada tahun 2016 suku bunga kredit di Kabupaten Tanjung Jabung Barat mencapai titik yang relatif rendah dibandingkan dengan periode-periode sebelumnya sebesar 11,21 persen penurunan ini ada kaitannya dengan penurunan inflasi yang terjadi pada tahun yang sama yaitu sebesar 3,02 persen. Menurunnya inflasi menyebabkan harga-harga barang pada umumnya akan menurun, sehingga apabila suku bunga kredit investasi tetap besar maka akan terjadi penurunan pada realisasi pinjaman investasi di 
Kabupaten Tanjung Jabung Barat, sehingga apabila tidak ingin terjadi maka suku bunga kredit juga harus diturunkan.

\section{Perkembangan inflasi}

Inflasi adalah kecenderungan akan naiknya harga barang-barang secara umum, yang berarti terjadinya penurunan nilai uang. Penyebab utama dan satu-satunya yang memungkinkan gejala ini muncul menurut teori kuantitas adalah terjadinya kelebihan uang yang beredar sebagai akibat penambahan jumlah uang di masyarakat (Rimsky, 2002). Berdasarkan tabel 3 dapat dilihat bahwa selama tahun 2004-2018 inflasi berfluktuasi setiap tahunnya. Rata-rata inflasi dari tahun 2004-2018 yaitu sebesar 5,58 persen, artinya inflasi Kabupaten Tanjung Jabung Barat berada pada tingkat 5,58 persen setiap tahunnya. Inflasi tertinggi tercatat pada tahun 2005 yaitu sebesar 16,50 persen, angka inflasi ini tertinggi selama periode 2004-2018. Tingginya inflasi yang terjadi pada tahun 2005 terjadi disebabkan banyak kebutuhan pokok seperti cabe dan bawang tidak cukup untuk memenuhi kebutuhan pembeli, sehingga harga melonjak naik dan terjadilah peningkatan inflasi yang signifikan. Sedangkan inflasi terendah tercatat pada tahun 2013 yaitu sebesar 1,04 persen, rendahnya inflasi tersebut terjadi karena daya beli masyarakat rendah sehingga tidak terjadinya kelangkaan suatu barang yang menyebabkan inflasi. Untuk melihat perkembangan inflasi di Kabupaten Tanjung Jabung Barat dapat kita lihat pada tabel berikut ini:

Tabel 3 Perkembangan inflasi di Kabupaten Tanjung Jabung Barat Tahun 2004 -2018

\begin{tabular}{cc} 
Tahun & $\begin{array}{c}\text { Inflasi } \\
(\boldsymbol{\%})\end{array}$ \\
\hline 2004 & 7,25 \\
2005 & 16,50 \\
2006 & 10,66 \\
2007 & 2,75 \\
2008 & 11,57 \\
2010 & 2,49 \\
2011 & 6,31 \\
2012 & 3,22 \\
2013 & 2,62 \\
2014 & 1,04 \\
2015 & 8,72 \\
2016 & 1,37 \\
2017 & 3,92 \\
2018 & 2,32 \\
Rata-Rata & 3,02 \\
\hline
\end{tabular}

Sumber : Bank Indonesia, 2020

\section{Analisis pertumbuhan ekonomi}

Pertumbuhan ekonomi adalah salah satu indikator yang digunakan untuk mengukur prestasi ekonomi suatu negara. Pertumbuhan ekonomi menggambarkan kenaikan taraf hidup diukur dengan output riil per orang. Berikut ini dapat dilihat pertumbuhan ekonomi di Kabupaten Tanjung Jabung Barat selama tahun 2004 sampai 2018 pada Tabel 4 berikut ini: 
Tabel 4. Perkembangan pertumbuhan ekonomi di Kabupaten Tanjung Jabung Barat Tahun 2004-2018

\begin{tabular}{cc}
\hline Tahun & Pertumbuhan Ekonomi $(\boldsymbol{\%})$ \\
\hline 2004 & 7,94 \\
2005 & 7,81 \\
2006 & 7,91 \\
2007 & 7,97 \\
2008 & 5,99 \\
2009 & 6,39 \\
2010 & 6,87 \\
2011 & 7,85 \\
2012 & 7,70 \\
2013 & 7,63 \\
2014 & 8,83 \\
2015 & 5,28 \\
2016 & 5,38 \\
2017 & 5,60 \\
2018 & 5,02 \\
\hline Rata-Rata & $\mathbf{6 , 9 4}$ \\
\hline
\end{tabular}

Sumber : BPS Provinsi Jambi, 2020 (diolah)

Berdasarkan Tabel 4 selama periode tahun 2004 sampai tahun 2018, rata-rata pertumbuhan ekonomi Kabupaten Tanjung Jabung Barat sebesar 6,94 persen. Pertumbuhan ekonomi tertinggi tercatat pada tahun 2014 yaitu sebesar 8,83 persen, hal ini dikarenakan pada tahun 2014 sektor pertambangan dan penggalian mendominasi kontribusi sektor PDRB atas harga konstan di Kabupaten Tanjung Jabung Barat dengan kontribusi terhadap PDRB sebesar 80,39 persen sehingga pertumbuhan ekonomi tertinggi tercatat pada tahun 2014.

Sedangkan pertumbuhan ekonomi terendah tercatat pada tahun 2018 yaitu sebesar 5,02 persen, rendahnya pertumbuhan ekonomi karena pada tahun 2018 sektor sektor industi pengolahan berkontribusi terhadap PDRB atas harga konstan sebesar 1,58 persen dan sektor pertambangan dan penggalian yang merupakan sektor migas juga mengalami penurunan pada tahun tersebut sehingga pertumbuhan ekonomi terendah tercatat pada tahun 2018.

Dari 17 sektor pembentuk PDRB, terdapat sektor-sektor yang berkontribusi besar dan kecil terhadap pertumbuhan ekonomi. Sektor terbesar yang berkontribusi dalam peningkatan pertumbuhan ekonomi di Kabupaten Tanjung Jabung Barat selama periode tahun 2004-2018 tercatat pada sektor pertambangan dan penggalian. Tingginya pertumbuhan sektor pertambangan dan penggalian sebagian besar disebabkan meningkatnya produksi minyak dan gas bumi akibat dari berproduksinya perusahaan pengeboran minyak di Kabupaten Tanjung Jabung Barat.Subsektor minyak dan gas merupakan sektor dominan yang mengakibatkan laju pertumbuhan sektor pertambangan dan penggalian secara keseluruhan. Selanjutnya sektor terkecil dalam kontribusinya terhadap pertumbuhan ekonomi di Kabupaten Tanjung Jabung Barat selama periode tahun 2004-2018 tercatat pada sektor industri pengolahan.

\section{Perkembangan permintaan kredit di BPR Tanggo Rajo}

Permintaan kredit adalah jumlah kredit modal kerja, kredit investasi dan kredit konsumtif yang disalurkan kepada nasabah peminjam pada BPR Tanggo Rajo. Berikut 
ini dapat dilihat permintaan kredit di BPR Tanggo Rajo selama tahun 2004-2018 pada Tabel 5 berikut ini :

Tabel 5 Perkembangan permintaan kredit di BPR Tanggo Rajo Tahun 2004-2018

\begin{tabular}{ccc}
\hline Tahun & Permintaan Kredit (Rp. Juta) & Perkembangan $(\%)$ \\
\hline 2004 & 5.388 & - \\
2005 & 6.924 & 28,51 \\
2006 & 8.227 & 18,82 \\
2007 & 11.286 & 37,18 \\
2008 & 13.109 & 16,15 \\
2009 & 13.786 & 5,16 \\
2010 & 12.648 & $-8,25$ \\
2011 & 13.017 & 2,92 \\
2012 & 13.206 & 1,45 \\
2013 & 16.876 & 27,80 \\
2014 & 11.231 & $-33,45$ \\
2015 & 13.206 & 17,58 \\
2016 & 15.405 & 16,66 \\
2017 & 17.605 & 14,28 \\
2018 & 19.805 & 12,49 \\
\hline Rata-Rata & & $\mathbf{1 1 , 2 4}$ \\
\hline
\end{tabular}

Sumber : BPR Tanggo Rajo, 2020(diolah)

Berdasarkan Tabel 5 diatas dapat dilihat bahwa perkembangan permintaan kredit pada BPR Tanggo Rajo selama tahun 2004-2018 mengalami perkembangan yang berfluktuasi, rata-rata perkembangan permintaan kreditnya sebesar 11,24 persen. Perkembangan tertinggi tercatat pada tahun 2007 yaitu 37,18 persen. Tingginya perkembangan tahun 2007 dikarenakan meningkatnya permintaan kredit konsumtif dan modal kerja. Sedangkan permintaan kredit juga mengalami penurunan dimana penurunan terparah tercatat pada tahun 2013 yaitu $-33,45$ perse atau menurun sebesar Rp. 5.645 juta dari tahun sebelumnya. Penurunan ini terjadi disebabkan karena inflasi yang tinggi yaitu sebesar 8,83 persen.

Pengaruh tingkat suku bunga kredit, inflasi dan pertumbuhan ekonomi terhadap permintaan kredit perbankan pada perbankan di BPR Tanggo Rajo

Berdasarkan analisis dengan program SPSS 20 for Windows diperoleh hasil regresi berganda seperti terangkum pada tabel berikut:

Tabel 6 Hasil uji regresi berganda

\begin{tabular}{|c|c|c|c|c|c|c|c|}
\hline \multirow{2}{*}{ Model } & \multicolumn{2}{|c|}{ Unstandardized Coefficients } & \multirow{2}{*}{$\begin{array}{l}\text { Standardized } \\
\text { Coefficients } \\
\text { Beta }\end{array}$} & \multirow{2}{*}{$\mathbf{t}$} & \multirow{2}{*}{ Sig. } & \multicolumn{2}{|c|}{$\begin{array}{l}\text { Collinearity } \\
\text { Statistics }\end{array}$} \\
\hline & B & Std. Error & & & & Tolerance & VIF \\
\hline 1 (Constant) & 41728,872 & 7323,592 & & 5,698 &, 000 & & \\
\hline SB & $-1399,290$ & 575,507 & -.538 & $-2,431$ & .033 & .434 & 2,302 \\
\hline INF & $-82,200$ & 194.827 & -.095 & -.422 & .681 & 419 & 2,388 \\
\hline $\mathrm{PE}$ & -1471.690 & 493.029 & -464 & -2.985 & .012 & 881 & 1.135 \\
\hline
\end{tabular}

a. Dependent Variable: PK

Sumber: Data diolah, 2020 
Berdasarkan tabel di atas diperoleh persamaan regresi berganda sebagai berikut:

$$
\mathrm{PK}=41728,872-1399,290 \mathrm{SB}-82,200 \mathrm{INF}-1471,690 \mathrm{PE}+\mathrm{e}
$$

Persamaan regresi tersebut mempunyai makna sebagai berikut Jika variabel suku bunga kredit, inflasi dan pertumbuhan ekonomi atau tidak berubah, maka variabel permintaan kredit akan meningkat sebesar 41728,872 juta rupiah. Jika variabel suku bunga kredit mengalami kenaikan sebesar satu persen, sementara inflasi dan pertumbuhan ekonomi dianggap tetap atau tidak berubah, maka akan menyebabkan penurunan permintaan kredit sebesar 1399,290 juta rupiah. Jika variabel pertumbuhan ekonomi mengalami kenaikan selama satu persem, sementara suku bunga kredit dan inflasi dianggap tetap atau tidak berubah, maka akan menurunkan permintaan kredit sebesar 1471,690 juta rupiah.

\section{Pengujian hipotesis}

\section{Pengujian hipotesis secara simultan (Uji F)}

Uji $F$ dilakukan untuk melihat pengaruh variabel independen secara simultan terhadap variabel dependen atau sering disebut uji kelinieran persamaan regresi.Untuk melakukan uji $\mathrm{F}$ dapat dilihat pada tabel anova dibawah ini:

Tabel 7 Hasil uji F statistik

\begin{tabular}{llrrrrr}
\hline Model & & Sum of Squares & df & Mean Square & F & \multicolumn{1}{c}{ Sig. } \\
\hline 1 & Regression & 162447787,163 & 3 & 54149262,388 & 11,984 &, $001^{\mathrm{b}}$ \\
& Residual & 49703747,770 & 11 & 4518522,525 & & \\
Total & 212151534,933 & 14 & & & \\
\hline
\end{tabular}

a. Dependent variable: PK

b. Predictors: (Constant), SB, INF, PE

Sumber: Data diolah, 2020

Pada tabel Anova diperoleh nilai $\mathrm{F}$ sig $=0,001<0,05$ ini berarti variabel independen suku bunga kredit, inflasi dan pertumbuhan ekonomi secara simultan benarbenar berpengaruh signifikan terhadap variabel dependen permintaan kredit.

\section{Pengujian hipotesis secara parsial (uji t)}

Uji $\mathrm{t}$ dilakukan untuk mengetahui apakah secara individu (parsial) variabel independen mempengaruhi variabel dependen secara signifikan atau tidak. Jika tingkat signifikansinya dibawah 5\% maka secara parsial variabel bebas berpengaruh terhadap variabel terikat.

Dari hasil pengujian diperoleh nilai $t$ hitung untuk variabel suku bunga kredit sebesar $-2,431$ dengan tingkat keyakinan $(\alpha=5 \%) \mathrm{df}=(11)$ untuk pengujian diperoleh nilai $\mathrm{t}$ tabel 1,7958 dari perhitungan tersebut dapat dilihat bahwa nilai $\mathrm{t}$ hitung lebih besar dari $\mathrm{t}$ tabel $(-$ 2,431 > 1,7958), artinya Ho ditolak dan Ha diterima artinya suku bunga kredit berpengaruh signifikan terhadap permintaan kredit di BPR Tanggo Rajo. Dengan demikian hipotesis 
yang menyatakan pengaruh suku bunga kredit terhadap permintaan kredit di BPR Tanggo Rajo benar dan terbukti.

Tabel 8. Hasil uji t statistik

\begin{tabular}{lrrrrrr}
\hline \multirow{2}{*}{ Model } & \multicolumn{2}{c}{ Unstandardized Coefficients } & \multicolumn{2}{c}{$\begin{array}{c}\text { Standardized } \\
\text { Coefficients }\end{array}$} & \multirow{2}{*}{ t } & \multirow{2}{*}{ Sig. } \\
\cline { 2 - 4 } & \multicolumn{1}{c}{ B } & \multicolumn{1}{c}{ Std. Error } & Beta & & \\
\hline 1 (Constant) & 41728,872 & 7323,592 & & & 5,698 &, 000 \\
SB & $-1399,290$ & 575,507 & &,- 538 & $-2,431$ &, 033 \\
INF & $-82,200$ & 194,827 & &,- 095 &,- 422 &, 681 \\
PE & $-1471,690$ & 493,029 & &,- 464 & $-2,985$ &, 012 \\
\hline
\end{tabular}

Sumber : Data diolah, 2020

Dari hasil pengujian diperoleh nilai $\mathrm{t}$ hitung untuk variabel inflasi sebesar $-0,422$ dengan tingkat keyakinan $(\alpha=5 \%) d f=(11)$ untuk pengujian diperoleh nilai $t$ tabel 1,7958 dari perhitungan tersebut dapat dilihat bahwa nilai $t$ hitung lebih kecil dari $t$ tabel $(0,422<$ 1,7958), artinya Ho diterima dan Ha ditolak artinya inflasi tidak berpengaruh signifikan terhadap permintaan kredit di BPR Tanggo Rajo. Dengan demikian hipotesis yang menyatakan pengaruh inflasi terhadap permintaan kredit di BPR Tanggo Rajo tidak benar dan tidak terbukti.

Dari hasil pengujian diperoleh nilai $\mathrm{t}$ hitung untuk variabel pertumbuhan ekonomi sebesar $-2,985$ dengan tingkat keyakinan $(\alpha=5 \%) \mathrm{df}=(11)$ untuk pengujian diperoleh nilai $\mathrm{t}$ tabel 1,7958 dari perhitungan tersebut dapat dilihat bahwa nilai $\mathrm{t}$ hitung lebih kecil dari $\mathrm{t}$ tabel ($2,985>1,7958)$, artinya Ho ditolak dan $\mathrm{Ha}$ diterina artinya pertumbuhan ekonomi berpengaruh signifikan terhadap permintaan kredit di BPR Tanggo Rajo. Dengan demikian hipotesis yang menyatakan pengaruh pertumbuhan ekonomi terhadap permintaan kredit di BPR Tanggo Rajo benar dan terbukti.

\section{Koefisien determinasi $\left(\mathbf{R}^{2}\right)$}

Analisis koefisiensi determinasi (KD) digunakan untuk melihat beberapa besar variabel bebas berpengaruh terhadap variabel terikat yang dinyatakan dalam persentase seperti yang ditunjukkan pada tabel berikut :

Tabel 9. Hasil uji $\mathrm{R}^{2}$ Square

\begin{tabular}{|c|c|c|c|c|c|c|c|c|c|c|}
\hline \multirow[b]{2}{*}{ Model } & \multirow[b]{2}{*}{$\mathbf{R}$} & \multirow[b]{2}{*}{ R Square $_{\mathbf{F}}$} & \multirow[b]{2}{*}{$\begin{array}{l}\text { Adjusted } \\
\text { R Square }\end{array}$} & \multirow{2}{*}{$\begin{array}{l}\text { Std. Error } \\
\text { of the } \\
\text { Estimate }\end{array}$} & \multicolumn{5}{|c|}{ Change Statistics } & \multirow[b]{2}{*}{$\begin{array}{l}\text { Durbin- } \\
\text { Watson }\end{array}$} \\
\hline & & & & & $\begin{array}{l}\text { R Square } \\
\text { Change }\end{array}$ & $\begin{array}{c}\text { F } \\
\text { Change }\end{array}$ & df1 & df 2 & $\begin{array}{c}\text { Sig. F } \\
\text { Change }\end{array}$ & \\
\hline 1 &, $875^{\mathrm{a}}$ & ,766 & ,702 & 2125,68166 & ,766 & 11,984 & 3 & 11 & ,001 & 1,479 \\
\hline
\end{tabular}

a. Predictors: (Constant), SB, INF, PE

b. Dependent Variable: PK

Sumber: Data diolah, 2020

Tabel 9 diatas dapat kita lihat model summary diketahui nilai $\mathrm{R}_{\text {square }}$ sebesar 0,766. Artinya sebesar 76,6 persen variasi permintaan kredit di BPR Tanggo Rajo dijelaskan oleh variabel bebas dalam model, sedangkan sisanya 23,4 persen dijelaskan oleh variabel lain diluar penelitian.

\section{Analisis ekonomi}

\section{Pengaruh suku bunga kredit terhadap permintaan kredit}

Berdasarkan hasil regresi diketahui bahwa suku bunga kredit berpengaruh signifikan terhadap permintaan kredit. Hasil penelitian sesuai dengan hipotesis yang 
diajukan, maka hipotesis penelitian diterima. Hasil penelitian ini sejalan dengan teori yang dikemukakan oleh Mankiw (2003) pengusaha menginginkan output perekonomian yang lebih banyak dari pada rumah tangga yang ingin menabung. Dengan kata lain, jumlah dana pinjaman yang diminta melebihi jumlah uang yang ditawarkan.

Berpengaruhnya suku bunga kredit terhadap permintaan kredit dikarenkan suku bunga kredit setiap tahunnya mengalami peningkatan dengan rata-rata peningkatan sebesar 13,05 persen pertahunnya. Peningkatan tersebut akan berdampak terhadap penduduk yang ingin mengajukan kredit, baik kredit modal kerja, kredit investasi dan kredit konsumtif akan menurun. Tingginya suku bunga kredit akan menyebabkan seseorang mengurungkan niatnya untuk mengajukan kredit.

\section{Pengaruh inflasi terhadap permintaan kredit}

Berdasarkan hasil regresi diketahui bahwa inflasi tidak berpengaruh signifikan terhadap permintaan kredit. Hasil ini tidak sependapat dengan penelitian yang dilakukan oleh Ningsih (2010) yang mengatakan permintaan kredit berjalan berlawanan arah dengan inflasi. Meningkatnya inflasi diakibatkan naiknya jumlah uang beredar dan akan berpengaruh pada nilai mata uang suatu negara semakin kecil, tingkat harga menjadi tinggi sehingga permintaan kredit akan turun. Sehingga pelaku bisnis enggan meminjam dana, hal ini disebabkan seseorang atau perusahaan memperhitungkan keuntungannya karena nantinya mereka harus mengembalikan dana tersebut dengan tingkat harga yang tinggi. Tidak berpengaruhnya inflasi terhadap permintaan kredit dikarenakan inflasi di Kabupaten Tanjung Jabung Barat terus mengalami perubahan naik turun setiap tahunnya, sehingga tidak bisa di prediksi oleh konsumen BPR Tanggo Rajo dan tidak mempertimbangkan nilai inflasi untuk mengajukan kredit.

\section{Pengaruh pertumbuhan ekonomi terhadap permintaan kredit}

Berdasarkan hasil regresi diketahui bahwa pertumbuhan ekonomi berpengaruh signifikan terhadap permintaan kredit. Hasil ini sependapat dengan penelitian yang dilakukan oleh Djati (2017) yang mengatakan bahwa pertumbuhan ekonomi memilki pengaruh positif terhadap pertumbuhan ekonomi, hal ini dikarenakan adanya pertumbuhan ekonomi yang mengalami peningkatan akan merangsang pelaku usaha atau investor untuk meningkatkan usahanya, dan pada akhirnya berdampak terhadap permintaan kredit..

\section{KESIMPULAN DAN SARAN}

\section{Kesimpulan}

Dari hasil dan pembahasan yang telah dikemukakan pada bab sebelumnya maka dapat diambil kesimpulan sebagai berikut Perkembangan tahunan Suku bunga kredit terlihat berfluktuasi, rata-rata suku bunga kredit selama periode penelitian tahun 20042018 adalah 13,05 persen pertahun. Selama tahun 2004-2018 inflasi berfluktuasi setiap tahunnya, dengan rata-rata inflasi dari tahun 2004-2018 yaitu sebesar 5,58 persen. Perkembangan inflasi selama periode tahun 2004 sampai tahun 2018, rata-rata pertumbuhan ekonomi Kabupaten Tanjung Jabung Barat sebesar 6,94 persen. Selama periode tahun 2004 sampai tahun 2018, rata-rata pertumbuhan ekonomi Kabupaten Tanjung Jabung Barat sebesar 6,94 persen. perkembangan permintaan kredit pada BPR Tanggo Rajo selama tahun 2004-2018 mengalami perkembangan yang berfluktuasi, rata-rata perkembangan permintaan kreditnya sebesar 11,24 persen. Berdasarkan hasil uji simultan bahwa variabel suku bunga kredit, inflasi dan pertumbuhan ekonomi secara 
bersama-sama berpengaruh signifikan terhadap permintaan kredit di BPR Tanggo Rajo. Sedangkan secara pasrial hanya varaibel suku bunga kredit dan pertumbuhan ekonomi yang berpengaruh signifikan dan negatif terhadap permintaan kredit di BPR Tanggo Rajo, sementara variabel inflasi tidak berpengaruh signifikan dan negatif terhadap permintaan kredit BPR Tanggo Rajo.

\section{Saran}

Dari hasil penelitian dan kesimpulan diatas maka dapat diberikan saran sebagai berikut Seharusnya otoritas keuangan pemerintah mengambil kebijakan untuk dapat menstabilkan suku bunga kredit agar permintaan kredit oleh masyarakat tidak menurun. Hasil dari penelitian menunjukkan bahwa pertumbuhan ekonomi memilki peran yang besar teradap peningkatan permintaan kredit di BPR Tanggo Rajo selama periode tahun 2004-2018. Alangkah baiknya bagi peneliti selanjutnya dapat memperluas ruang lingkup penelitian yang akan dilakukan sehingga hasil yang ditemukan akan lebih baik lagi. Mengingat inflasi tidak memilki pengaruh terhadap permintaan kredit di BPR Tanggo Rajo selama periode 2004-2018. Untuk itu bagi peneliti selanjutnya yang akan meneliti dengan judul yang berkaitan dengan penelitian ini, perlu mempertimbangkan inflasi sebagai variabel penelitian.

\section{DAFTAR PUSTAKA}

Bank Indonesia, (2015). Laporan perekonomian indonesia Tahun 2015, diakses dalam http://bi.go.id, Tanggal 22 Februari 2018, Pukul 08.00 WIB

Bank Indonesia, (2017). Laporan perekonomian indonesia tahun 2017, diakses dalam http://bi.go.id, Tanggal 22 Februari 2018, Pukul 08.00 WIB

Gujarati, Damodar. (2003). Ekonometri dasar. Terjemahan: Sumarno Zain, Erlangga: Jakarta.

Lubis, (2010). Perbankan Indonesia. Pustaka Utama: Jakarta

Mankiw, N, G., (2007). Makroekonomi . Edisi Keenam. Erlangga: Jakarta

Mankiw, N, G., (2012). Principles of economics pengantar ekonomi makro. edisi 3. salemba empat: jakarta

Mankiw, N. Gregory. (2003). Teori Makroekonomi Edisi Kelima. Terjemahan. Erlangga: Jakarta

Ningsih, D., dan Zuhroh, I., (2010). Analisis permintaan kredit investasi pada bank swasta Nasional Di Jawa Timur. Jurnal Ekonomi Pembangunan, 8(2), 345-356

R Nofitasari, A Amir, C Mustika.(2017).Pengaruh inflasi, suku bunga, investasi terhadap pertumbuhan ekonomi Provinsi Jambi, e-Jurnal Perspektif Ekonomi dan Pembangunan Daerah 6 (2), 77-84

T Yudiarti, E Emilia, C Mustika.(2018).Pengaruh utang luar negeri, tingkat suku bunga dan neraca transaksi berjalan terhadap nilai tukar Rupiah terhadap Dolar Amerika Serikat.-Jurnal Perdagangan Industri dan Moneter 6 (1), 14-22

Totok, Sigit Triandaru. (2006). Bank dan lembaga keuangan lain. Edisi 2. Salemba Empat: Jakarta.

Winarsih, E., M. Adenan., dan A. Jumiati. (2015). Pengaruh pertumbuhan ekonomi, nilai tukar, tingkat bunga, dan inflasi terhadap permintaan kredit di Indonesia (Studi Kasus Bank Umum Periode 2008Q1-2015Q4). Skripsi Universitas Jember: Jawa Timur 